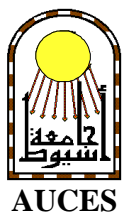

\title{
EFFECT OF DRINKING NATURAL SALINE GROUNDWATER ON GROWTH PERFORMANCE, BEHAVIOR AND SOME BLOOD PARAMETERS IN RABBITS REARED IN NEW RECLAIMED LANDS OF ARID AREAS IN ASSIUT GOVERNORATE
}

\author{
Moustafa M. Ahmed and Moataz A. Abdel-Rahman* \\ Department of Animal Hygiene, Faculty of Veterinary Medicine, Assiut University . \\ *Animal Behavior and Management
}

\begin{abstract}
:
This experiment was carried out to study the effect of drinking natural saline well-water on growth performance, behavior, reproduction and some blood parameters of rabbits reared in the new reclaimed lands of arid areas in Assiut Governorate. Two trials were carried out in the present investigation, the first one was carried out on growing rabbits of Baladi, Bouscat and California species to determine the effect of drinking natural saline well water on growth performance and blood cortisol, metabolites and mineral levels. However, the second trial was carried out on multiparous does of the same species to determine the effect of drinking natural saline well water on reproductive and maternal behavior of rabbits.

Allover 60 days experimental period, a group of each breed used in the first and second trials was allowed to freely drink fresh tap water while the other group was allowed to drink natural saline underground well water. Growing rabbits were weighed by the end of the 60 day experimental period to determine the average total as well as daily weight gain for each breed and blood samples were taken and analyzed for their cortisol, some metabolites and mineral levels. However, does were investigated for their reproductive and maternal behavior.

The obtained results indicated that, in spite of the significant elevation of some metabolites and mineral levels of their blood, experimented rabbits could tolerate the salinity of normal saline wellwater without deterioration effects either on their growth and reproductive performances or on their maternal behavior. Therefore, there are no problems with the use of underground water for drinking of rabbits reared in farms erected in the new reclaimed arid lands.
\end{abstract}

\section{INTRODUCTION:}

Water is the most important nutrient for livestock. It is second to oxygen as immediately essential for life. The quality and quantity of drinking water may affect feed consumption and animal health since low quality water normally results in reduced water and feed consumption in livestock, especially rabbits. Moreover, water salinity is the major factor determining the suitability of particular water source for livestock. Certain salts and gases in solution make water more palatable, if not present in excess, while various salts may reduce water palatability and may be toxic at high 
levels (Cheeke, 1987; Ray, 1989, Willis, 1991 and Sandford, 1996).

New reclaimed desert areas depend on under groundwater for drinking of animals reared in farms erected in these desert lands. Recent Egyptian agriculture policy has been directed towards intensive land reclamation in the desert areas. Animals in these areas are usually dependent on drinking well water with varying degrees of salinity.

Several trials have been conducted to study the effect of utilizing natural saline water on different animals (Andersen and Stothers, 1978 with pigs, Kamel et al., 1984 with goats, Ahmed et al., J985 and 1989 with sheep, Challies et al., 1987 with cattle, and Balnave \& Yoselewitz, 1988 with poultry). However, rabbits received a little attention in this respect although it is considered as a useful contribution to the meat supply in developing countries, which suffer from animal protein shortage. In Egypt, Ayyat et al. (1991) studied this aspect on rabbits using synthetic saline water.

Therefore, the present experiment was carried out to study the effect of drinking natural saline well-water on growth performance, behavior, reproduction and some blood parameters of Baladi, Bouscat and California rabbits and so, it can be considered as a guide for extension or limiting rabbitries construction in desert areas.

\section{MATERIALS AND METHODS:}

This experiment was carried out in one of the owner's farms that held in the new reclaimed lands of arid areas in Assiut Governorate. Two trials were carried out in the present investigation, the first one was carried out on growing rabbits to determine the effect of drinking natural saline well water on growth performance and blood cortisol, metabolites and mineral levels. However, the second trial was carried out on multiparous does to determine the effect of drinking natural saline well water on reproductive and maternal behavior of rabbits.

\section{A- First trial:}

\section{I-Animals used:}

30 growing rabbits of 8 weeks old were used in this trial. 10 rabbits were of Baladi breed with average weight $550 \mathrm{gm}, 10$ rabbits were of Bouscat breed with average weight $700 \mathrm{gm}$, while the last 10 rabbits were of California breed with average weight $700 \mathrm{gm}$. Animals of each breed were randomly divided into two groups, each of five. Animals of each group were housed together in a suitable galvanized metal cage provided with feeders and drinkers and all groups were housed in a well ventilated and well lighted suitable room under the prevalent environmental conditions.

\section{II- Experimental design:}

Allover 60 days experimental period, a group of each breed was allowed to freely drink fresh tap water while the other group was allowed to drink natural saline underground well water. Tap water and natural saline underground well water used in this experiment were analyzed chemically according to Muller (1995) and the result of this analysis was presented in table (1). Allover the experiment, animals were freely fed the pelleted commercial concentrate mixture and barseem.

Average daily water and feed intake were recorded using the weight back techniques according to Pond et al. (1995).

Rabbits were weighed by the end of the 60 day experimental period to determine the average total as well as daily weight gain for each breed. 
Table (1): pH and salts concentrations (p.p.m) of used fresh tap water and natural saline well water

\begin{tabular}{||l|c|c||}
\hline Parameter & $\begin{array}{c}\text { Fresh tap } \\
\text { water }\end{array}$ & $\begin{array}{c}\text { Natural saline } \\
\text { well water }\end{array}$ \\
\hline pH & 7.5 & 7.8 \\
Total salinity & $\mathbf{5 5 6}$ & $\mathbf{2 9 8 0}$ \\
Calcium & $\mathbf{9 2}$ & $\mathbf{2 1 8}$ \\
Magnesium & 11 & 107 \\
Potassium & 18 & 38 \\
Sodium & 180 & 373 \\
Manganese & 10 & 14 \\
Carbonate & 0 & 8 \\
Bicarbonate & 18 & 130 \\
Sulfate & 15 & 580 \\
Chloride & 110 & $\mathbf{8 0 0}$ \\
\hline
\end{tabular}

III-Blood cortisol, metabolites and mineral levels:

By the end of the experimental period, a blood sample $(3 \mathrm{ml}$ each) was collected from each rabbit from the ear vein on the wall of a centrifuge tube following the rules of Suckow \& Douglas (1997) and Afifi \& Daghash (1999). The sera of the collected samples were separated by centrifugation at 3000 r.p.m for 30 minutes and were freezed at $-20{ }^{\circ} \mathrm{C}$ until analysis.

The harvested sera were estimated for their levels of cortisol according to Dandliker \& Feigen (1970) and Dandliker \& Saussure (1973) using TDx FLx system with fluorescence polarization and competitive binding techniques.

Sera were also estimated for their levels of cholesterol, total lipids, total protein, $\mathrm{Na}, \mathrm{K}, \mathrm{Ca}$, and $\mathrm{Mg}$ using the methods described by Tietz (1982).

\section{B- Second trial:}

\section{I- Animals used:}

30 multiparous 1-1.5 years old does were used in this investigation. 10 does were of Baladi breed with average weight $2-2.5 \mathrm{~kg}, 10$ rabbits were of Bouscat breed with average weight 3.5-4 $\mathrm{kg}$, while the last 10 rabbits were of California breed with average weight $3.5-4 \mathrm{~kg}$. Does of each breed were randomly assigned into two groups, each of five. Each doe was housed in a suitable galvanized metal cage provided with feeders, drinkers, nest box and nesting materials. However, all groups were housed in a well-ventilated and well-lighted suitable room under the prevalent environmental conditions.

\section{II- Experimental design:}

Allover 60 days experimental period, a group of each breed was allowed to freely drink the previously analyzed fresh tap water while the other group was allowed to drink the previously analyzed natural saline underground well water. Allover the experiment, animals were freely fed the pelted commercial concentrates mixture and barseem. Moreover, several matings took place during the $3^{\text {rd }}$ and $4^{\text {th }}$ week of the experiment where each doe was transferred to the pen of a buck of the same breed (more than one year old) and returned to her own pen after mating. A successful mating being achieved by noticing the doe lifting her hind quarters towards the buck and after mating, the buck being fallen over side way giving a special cry.

\section{III- Reproductive performance:}

Reproductive performance of the experimented does was measured according to Abdel-samee \& El-Masry (1992); Mervat (1993) and Afifi \& Daghash (1999) as follows:

1-Conception rate $(\%$ of conceived does after several mating).

2-Gestation length of conceived does.

3-Litter size (the number of the newly born young at birth).

4-Viability of young at birth (number of live newly born young at birth).

5 -Viability of young at weaning. 
6-Bunny birth weight.

7-Bunny weaning weight.

8-Bunny weight gain from birth to weaning.

\section{IV- Maternal behaviour measurements:}

The maternal behaviour of the does under experiment was examined as follows:

1-Presence or absence of nest in the nesting box (Numan, 1978).

2-Measuring of retrieving: The retrieving was measured according to Jakubowski and Terkel (1986) where the does living with their newly born young rabbits were separated away 30 minutes prior to the test and then reunited with their young after being scattered infront of the nest and the dam was observed continuously for 30 minutes. The newly born retrieval was scored if the dam carried at least two of her newly born young to the nest site.
3-Physical contact: The dam was considered good if she was in contact with her all newly born young or all except one or two (Mervat, 1993).

4-Percentage of suckling: Where the percentage of suckled newly born young at the first day post-partum was recorded ((Mervat, 1993).

5-Abnormal behavior: Where any abnormal behavioral patterns of the examined does were recorded.

\section{C-Statistical analyses:}

Statistical analyses of the collected data were carried out according to procedures of completely random design, SAS (1995).

\section{RESULTS:}

The results of this study were illustrated in tables 2,3,4, 5 and 6 .

Table (2): Effect of drinking natural saline well water on feed intake and growth performance of growing rabbits

\begin{tabular}{|c|c|c|c|c|}
\hline \multirow{2}{*}{ Item } & \multirow{2}{*}{ Breed } & \multicolumn{2}{|c|}{ treatment } & \multirow{2}{*}{ "P" value } \\
\hline & & Fresh tap water & Natural saline well water & \\
\hline \multirow{3}{*}{$\begin{array}{c}\text { Daily water intake } \\
(\mathrm{ml})\end{array}$} & Baladi & $143 \pm 11$ & $208 \pm 9$ & $<0.01$ \\
\hline & Bouscat & $148 \pm 9$ & $212 \pm 7$ & $<0.01$ \\
\hline & California & $151 \pm 12$ & $214 \pm 11$ & $<0.01$ \\
\hline \multirow{3}{*}{$\begin{array}{l}\text { Daily concentrates } \\
\text { intake (g) }\end{array}$} & Baladi & $140 \pm 4$ & $138 \pm 5$ & NS \\
\hline & Bouscat & $160 \pm 5$ & $154 \pm 4$ & NS \\
\hline & California & $160 \pm 7$ & $155 \pm 4$ & NS \\
\hline \multirow{3}{*}{$\begin{array}{l}\text { Daily Barseem } \\
\text { intake (g) }\end{array}$} & Baladi & $100 \pm 5$ & $135 \pm 9$ & $<0.01$ \\
\hline & Bouscat & $120 \pm 9$ & $160 \pm 5$ & $<0.01$ \\
\hline & California & $125 \pm 11$ & $160 \pm 5$ & $<0.01$ \\
\hline \multirow{3}{*}{$\begin{array}{c}\text { Initial body weight } \\
\text { (g) }\end{array}$} & Baladi & $550 \pm 30$ & $550 \pm 30$ & NS \\
\hline & Bouscat & $700 \pm 20$ & $700 \pm 20$ & NS \\
\hline & California & $700 \pm 30$ & $700 \pm 30$ & NS \\
\hline \multirow{3}{*}{$\begin{array}{l}\text { Final body weight } \\
\text { (g) }\end{array}$} & Baladi & $2070 \pm 40$ & $2030 \pm 50$ & NS \\
\hline & Bouscat & $2310 \pm 50$ & $2280 \pm 50$ & NS \\
\hline & California & $2390 \pm 40$ & $2370 \pm 40$ & NS \\
\hline \multirow{3}{*}{$\begin{array}{l}\text { Daily body gain } \\
\text { (g) }\end{array}$} & Baladi & $25.3 \pm 0.1$ & $24.6 \pm 0.3$ & NS \\
\hline & Bouscat & $26.8 \pm 0.3$ & $26.3 \pm 0.5$ & NS \\
\hline & California & $28.2 \pm 0.1$ & $27.8 \pm 0.1$ & NS \\
\hline
\end{tabular}

NS = Not Significant 
Table (3): Effect of drinking natural saline well water on blood metabolites and mineral levels of growing rabbits

\begin{tabular}{|c|c|c|c|c|}
\hline \multirow{2}{*}{ Item } & \multirow{2}{*}{ Breed } & \multicolumn{2}{|c|}{ treatment } & \multirow{2}{*}{ "P" value } \\
\hline & & Fresh tap water & Natural saline well water & \\
\hline \multirow{2}{*}{$\begin{array}{c}\text { Cholesterol } \\
(\mathrm{mg} / \mathrm{dl})\end{array}$} & Baladi & $46.3 \pm 1.6$ & $81.3 \pm 1.3$ & $<0.01$ \\
\hline & Bouscat & $51.2 \pm 2.3$ & $92.5 \pm 3.1$ & $<0.01$ \\
\hline \multirow{3}{*}{$\begin{array}{c}\text { Total lipids } \\
\text { (mg/dl) }\end{array}$} & Baladi & $226.8 \pm 8.6$ & $288.3 \pm 6.1$ & $<0.01$ \\
\hline & Bouscat & $233.9 \pm 9.6$ & $292.1 \pm 6.2$ & $<0.01$ \\
\hline & California & $228.3 \pm 8.3$ & $296.4 \pm 7.1$ & $<0.01$ \\
\hline \multirow{2}{*}{$\begin{array}{l}\text { Total protein } \\
\text { (g/dl) }\end{array}$} & Bouscat & $6.8 \pm 0.04$ & $2.9 \pm 0.05$ & $<0.01$ \\
\hline & California & $7.2 \pm 0.08$ & $3.1 \pm 0.05$ & $<0.01$ \\
\hline \multirow{3}{*}{$\begin{array}{l}\text { Sodium } \\
(\mathrm{mEq} / \mathrm{L})\end{array}$} & Baladi & $138.3 \pm 9.6$ & $181.2 \pm 6.2$ & $<0.01$ \\
\hline & Bouscat & $133.5 \pm 8.3$ & $178.4 \pm 7.1$ & $<0.01$ \\
\hline & California & $141.1 \pm 8.9$ & $188.1 \pm 7.3$ & $<0.01$ \\
\hline $\begin{array}{l}\text { Potassium } \\
(\mathrm{mEq} / \mathrm{L})\end{array}$ & Baladi & $6.7 \pm 0.3$ & $4.1 \pm 0.1$ & $<0.01$ \\
\hline $\begin{array}{c}\text { Calcium } \\
\text { (mg/dl) }\end{array}$ & California & $11.6 \pm 0.8$ & $14.1 \pm 0.7$ & $<0.01$ \\
\hline \multirow{3}{*}{$\begin{array}{l}\text { Phosphorus } \\
\text { (mg/dl) }\end{array}$} & Baladi & $7.1 \pm 0.2$ & $5.7 \pm 0.1$ & $<0.01$ \\
\hline & Bouscat & $6.8 \pm 0.2$ & $5.4 \pm 0.1$ & $<0.01$ \\
\hline & California & $7.3 \pm 0.1$ & $5.9 \pm 0.1$ & $<0.01$ \\
\hline \multirow{3}{*}{$\begin{array}{l}\text { Magnesium } \\
(\mathbf{m g} / \mathbf{d l})\end{array}$} & Baladi & $5.5 \pm 0.1$ & $5.9 \pm 0.2$ & NS \\
\hline & Bouscat & $5.1 \pm 0.1$ & $5.7 \pm 0.1$ & NS \\
\hline & California & $5.8 \pm 0.3$ & $6.1 \pm 0.1$ & NS \\
\hline
\end{tabular}

Table (4): Effect of drinking natural saline well water on blood cortisol level ( $\mu \mathrm{g} / \mathrm{dl}$ ) of growing rabbits

\begin{tabular}{||c|c|c|c|c||}
\hline \hline \multirow{2}{*}{ Item } & \multirow{2}{*}{ Breed } & treatment & \multirow{2}{*}{ "P" value } \\
\cline { 3 - 4 } & Baladi & Fresh tap water & Natural saline well water & NS \\
Cortisol $(\mu \mathrm{g} / \mathrm{dl})$ & Bouscat & $\mathbf{1 . 5 1} \pm \mathbf{0 . 1}$ & $\mathbf{1 . 8 \pm 0 . 1}$ & NS \\
& California & $\mathbf{1 . 5 7 \pm 0 . 1}$ & $\mathbf{1 . 9 \pm 0 . 1}$ & NS \\
\hline \hline
\end{tabular}

Table (5): Effect of drinking natural saline well water on reproductive performance of experimented rabbits

\begin{tabular}{|c|c|c|c|c|}
\hline \multirow{2}{*}{ Item } & \multirow{2}{*}{ Breed } & \multicolumn{2}{|c|}{ treatment } & \multirow{2}{*}{ "P" value } \\
\hline & & Fresh tap water & Natural saline well water & \\
\hline \multirow{2}{*}{$\begin{array}{c}\text { Conception rate } \\
(\%)\end{array}$} & Baladi & 60 & 60 & NS \\
\hline & Bouscat & 80 & 80 & NS \\
\hline \multirow{3}{*}{$\begin{array}{c}\text { Gestation length } \\
\text { (day) }\end{array}$} & Baladi & 30 & 31 & NS \\
\hline & Bouscat & 31 & 31 & NS \\
\hline & California & 31 & 32 & NS \\
\hline \multirow{2}{*}{$\begin{array}{l}\text { Litter size at birth } \\
\quad \text { (No./birth) }\end{array}$} & Bouscat & 8 & 6 & NS \\
\hline & California & 8 & 8 & Ns \\
\hline \multirow{3}{*}{$\begin{array}{c}\text { Viability at birth } \\
(\%)\end{array}$} & Baladi & 80 & 80 & $\mathbf{N S}$ \\
\hline & Bouscat & 100 & 100 & NS \\
\hline & California & 100 & 100 & NS \\
\hline $\begin{array}{l}\text { Viability at weaning } \\
\qquad(\%)\end{array}$ & Baladi & 60 & 80 & $<0.05$ \\
\hline Bunny birth weight (g) & California & $60.8 \pm 3.8$ & $62.3 \pm 4.1$ & NS \\
\hline \multirow{3}{*}{$\begin{array}{c}\text { Bunny weaning weight } \\
\text { (g) }\end{array}$} & Baladi & $288.3 \pm 8.1$ & $335.2 \pm 5.3$ & $<0.05$ \\
\hline & Bouscat & $345.1 \pm 5.6$ & $398.2 \pm 3.8$ & $<0.05$ \\
\hline & California & $339.3 \pm 6.2$ & $391.2 \pm 4.8$ & $<0.05$ \\
\hline \multirow{3}{*}{$\begin{array}{l}\text { Bunny gain from birth } \\
\text { to weaning (g) }\end{array}$} & Baladi & $246.2 \pm 5.3$ & $289.9 \pm 2.8$ & $<0.05$ \\
\hline & Bouscat & $286.9 \pm 0.5$ & $338.1 \pm 0.6$ & $<0.05$ \\
\hline & California & $278.5 \pm 2.4$ & $328.9 \pm 0.7$ & $<0.05$ \\
\hline
\end{tabular}

NS = Not Significant 
Table (6): Effect of drinking natural saline well water on maternal behavior of experimented rabbits

\begin{tabular}{|c|c|c|c|c|}
\hline \multirow{2}{*}{ Item } & \multirow{2}{*}{ Breed } & \multicolumn{2}{|c|}{ treatment } & \multirow{2}{*}{ "P" value } \\
\hline & & Fresh tap water & Natural saline well water & \\
\hline \multirow{3}{*}{$\begin{array}{c}\text { Nest building } \\
(\%)\end{array}$} & Baladi & 100 & 100 & NS \\
\hline & Bouscat & 100 & 100 & NS \\
\hline & California & 100 & 100 & NS \\
\hline \multirow{3}{*}{$\begin{array}{c}\text { Retrieving } \\
(\%)\end{array}$} & Baladi & 100 & 100 & NS \\
\hline & Bouscat & 100 & 100 & NS \\
\hline & California & 100 & 100 & NS \\
\hline \multirow{3}{*}{$\begin{array}{l}\text { Physical contact } \\
\text { (\%) }\end{array}$} & Baladi & 100 & 100 & NS \\
\hline & Bouscat & 100 & 100 & NS \\
\hline & California & 100 & 100 & Ns \\
\hline \multirow{3}{*}{$\begin{array}{l}\text { Suckling } \\
(\%)\end{array}$} & Baladi & 100 & 100 & NS \\
\hline & Bouscat & 100 & 100 & NS \\
\hline & California & 100 & 100 & NS \\
\hline \multirow{3}{*}{ Abnormal behavior } & Baladi & No & No & NS \\
\hline & Bouscat & No & No & NS \\
\hline & California & No & No & NS \\
\hline
\end{tabular}

NS = Not Significant

\section{DISCUSSION:}

Water requirements of domestic rabbits are relatively high. Rabbits can lose nearly all the fat and more than half the protein from their bodies and still remain alive, but a loss of one tenth of the water of the body will result in death. Furthermore, rabbits can live for a relatively long time without solid food, but lack of water produces a very quick harmful effects (Sandford, 1996).

\section{I-Feed intake and growth performance:}

The data represented in table (2) showed the effect of drinking natural saline groundwater on the daily water intake, concentrates intake, Barseem intake as well as the daily body gain of growing Baladi, Bouscat and California rabbits. These data indicated that, drinking natural saline well water had a significant effect on both daily water and Barseem intakes of all experimented animals $(\mathbf{p}<0.01)$. However, niether of daily concentrates intake nor daily body gain was significantly affected, either with Baladi, Bouscat or california growing rabbits.

The averages of daily water intake by the corresponding rabbit species were 143, 148, 151 and 208, 212, $214 \mathrm{ml}$ using fresh tap water and natural saline well water, respectively. At the same time, the daily averages of barseem intake were 100, 120, 125 and 135, 160, $160 \mathrm{gm}$, respectively. This result illustrated that, both of daily water intake and daily barseem intake were significantly increased with the use of natural saline well water as a drinking one, a finding which agreed with Ahmed et al. (1989) using sheep; Ayyat et al. (1991) and AbdelSamee \& El-Masry (1992) using rabbits. The obtained results may related to the fact that drinking a high level of saline water increases the need for water used in the excretion of the most anions and cations through increasing water output and so, the animal increases its water intake either through drinking a large amount of it or eating a large amount of the green forages with higher water level (Baile and McLaughlin, 1987; pond et al., 1995; Guyton and Hall, 1996 and Suckow \& Douglas, 1997).

\section{II-Blood metabolites and mineral levels:}

The data represented in table (3) showed the effect of drinking natural saline well water on some blood metabolites and minerals of growing Baladi, Bouscat and California rabbits. These data indicated that, the measured blood metabolites (cholesterol, total lipids and total 
protein) were significantly affected $(\mathbf{p}<0.01)$ with the use of natural saline well water as a drinking one. The level of these metabolities in the blood of Baladi, Bouscat and California growing rabbits were 46.3, 51.2, 48.1 and 81.3, 92.5, 87.2 $\mathrm{mg} /$ dl for cholesterol; 226.8, 233.9, 228.3 and 288.3, 292.1, $296.4 \mathrm{mg} / \mathrm{dl}$ for total lipids; 7.1, 6.8, 7.2 and 3.8, 2.9, 3.1 g/dl for total protein using fresh tap water and natural saline well water for drinking, respectively.

This finding indicated that, the level of cholesterol and total lipids in the blood of experimented rabbitsd were significantly increased with drinking natural saline well water, a finding that may attributed to the effect of the used water salinity on the renal system and thyroid hormones with a defect in lipoprotein metabolism resulting in increasing the high density lipoproteins in the blood, which are the cholesterol-rich lipoprotein fractions. Intern, the elevated levels of cholesterol and lipoproteins resulted in a significant elevation in the blood total lipids (Ellefson \& Garaway, 1982; Abdel-Samee \& El-Masry, 1992 and Pond et al., 1995).

At the same time, the level of total protein in the blood of experimented rabbits was significantly decreased with drinking natural saline well water. This result may related to the fact that water is held bach to the body fluids to dilute out the retained salts, resulting in dilution of blood proteins and so, decreases its concentration level (Tietz, 1982; Ayyat et al., 1991 and Suckow \& Douglas, 1997).

With regard to blood mineral levels, the data illustrated in table (3) showed that serum levels of sodium, potassium, calcium and phosphorus were significantly affected with drinking natural saline well water $(\mathbf{p}<0.01)$, however, magnesium level was not significantly affected. The level of these minerals in the blood of Baladi, Bouscat and California rabbits following drinking of fresh tap water and natural saline well water were 138.3, 133.5, 141.1 and 181.2, 178.4, 188.1 $\mathrm{mEq} / \mathrm{L}$ for sodium; 6.7, 7.1, 6.8 and 4.1, 3.9, $4.3 \mathrm{mEq} / \mathrm{L}$ for potassium; 11.2, 11.8, 11.6 and 13.9, $13.8,14.1 \mathrm{mg} / \mathrm{dl}$ for calcium; 7.1, 6.8, 7.3 and $5.7,5.4,5.9 \mathrm{mg} / \mathrm{dl}$ for phosphorus, respectively.

This result indicated that, drinking natural saline well water resulted in a significant increase in the blood sodium and calcium levels and a significant decrease in the blood potassium and phosphorus concentrations, a finding which agreed with Tomas et al. (1973) with sheep and Abdel-Samee \& El-Masry (1992) with rabbits and could be attributed to the contrary trend between blood sodium and potassium concentrations to protect the body against hyperkalemia and so protect the body against muscle irritability. So, increased level of sodium ions in natural saline well water resulted in increased rate of its reabsorption, resulted in a decreased reabsorption of potassium (Crane, 1965; Grodsky, 1979; Tietz, 1982; Gary \& Narang, 1985 and Abdel-Samee \& El-Masry, 1992).

At the same time, increased calcium level in natural saline well water resulted in increased rate of its reabsorption and so, its blood level with decreased phosphorus level due to their reciprocal reverse relationship as the increased blood calcium level resulted in increased parathyroid hormone secretion which inhibits the renal tubules reabsorption of phosphorus (Tyler, 1979).

\section{III- Serum cortisol level:}

Cortisol and corticosterone are the principle glucosides of the adrenal cortex. Cortisol predominates in rabbit, mouse and rat. Large ruminants are intermediate case while cortisol is the major corticosteroid secreted by sheep 
(Linder, 1959 and Paterson, 1964). Studies on the circulating levels of adrenal corticosteroids showed a marked rise of these levels after exposure to any stressful conditions (Elizabeth and Huda, 1985; Shutt et al., 1988; Minton and Bleacha, 1990 and Parrott et al., 1996).

In the present study, serum cortisol level of the experimented Baladi, Bouscat and california rabbits as a result of drinking fresh tap water and natural saline well water were $1.51,1.62$, 1.57 and 1.81, 1.88, 186, respectively (table 4). This finding revealed that, serum cortisol level of the experimented rabbits was not significantly increased following their drinking natural saline well water and so, natural saline well water was not considered as an effective stress factor on rabbits that drink it.

\section{IV-Reproductive performance of the experimented rabbits:}

The data represented in table (5) showed the effect of drinking natural saline water on average conception rate, gestation length, litter size at birth, viability of young at birth, viability of young at weaning, bunny birth weight, bunny weaning weight and bunny gain from birth to weaning of Baladi, Bouscat and California rabbits. The obtained data indicated that, drinking natural saline well water had a significant effect on the viability of young at weaning, average bunny weaning weight and bunny gain from birth to weaning of all experimented animals $(p<0.05)$. However, niether of average conception rate, gestation length, litter size at birth, viability of young at birth nor bunny birth weight were significantly affected, either with Baladi, Bouscat or california rabbits.

Viability of youngs at weaning were 60,80 , 60 and $80,100,80 \%$, however, average bunny weaning weight were $288.3,345.1,339.3$ and
335.2, 398.2, $391.2 \mathrm{gm}$ using fresh tap water and natural saline well water, respectively. At the same time, average bunny gain from birth to weaning were 246.2, 286.9, 278.5 and 289.9, 338.1, 328.9 gm, respectively. This result illustrated that, both of viability of young at weaning, bunny weaning weight and bunny gain from birth to weaning were significantly increased with the use of natural saline well water as a drinking one. Such finding was agreed with Ayyat et al. (1991) and AbdelSamee \& El-Masry (1992) and may related to the fact that drinking saline water leads to increased average water intake and so, increased the dam's milk yield which reflected positively and significantly of their bunny health, weight and gain.

\section{V-Maternal behavior of the experimented rabbits:}

The data represented in table (6) showed the effect of drinking natural saline well water on the bevavior of nest building, retrieving, physical contact and suckling of Baladi, Bouscat and California does. These data indicated that, the previously mentioned bevaviors were not significantly affected with drinking the experimented Baladi, Bouscat and California does natural saline well water. Moreover, the experimented does did not show any abnormal behavior.

\section{CONCLUSION:}

It can be concluded that, in spite of the significant elevation of some metabolites and mineral levels in blood of Baladi, Bouscat and California rabbits, they could tolerate the salinity of normal saline well-water without deterioration effects either on their growth and reproductive performances or on their maternal 
behavior. Therefore, there are no problems with the use of underground water for drinking of rabbits reared in farms erected in the new reclaimed arid lands.

\section{REFERENCES:}

Abdel-Samee, A.M. and El-Masry, K.A. (1992): Effect of drinking natural saline well water on some productive and reproductive performance of California and New-Zealand white rabbits maintained under North Sinai conditions. Egypt J. Rabbit Sci., 2 (1): 1-11.

Ahmed, M.H.; Farid, M.F.A.; Hassan, N.I.; Borhami, B.E. and Shawket, S.M. (1985): Effect of drinking saline well water in sheep. $1^{\text {st }}$ Inter. Cong. Anim. Prod. In Arid Zone, Damascus, Syria.

Ahmed, M.H.; Farid, M.F.A.; Shawket, S.M. and Hassan, N.I. (1989): Effect of water deprivation on feed utilization and mineral balances in sheep drinking natural saline well water. J. Arid Environment, 16: 323-329.

Afifi, D.S. and Daghash, H.A. (1999): Reproductive performance of California doe rabbits as affected by feeding freshly Nigella Sativa seeds. Alex. J. Vet. Sci., 15 (5): 995-1008.

Anderson, D.M. and Stothers, S.C.(1978): Effect of saline water high in sulfates, chlorides and niterates on the performance of young weanling pigs. J. Anim. Sci., 47: 900-909.

Ayyat, M.S.; Habeeb, A.A. and Bassuny, S.M. (1991): Effect of water salinity on growth performance, carcas traits and some physiological aspects of growing rabbits in summer season. Egypt J. Rabbit Sci., 1: 21-34.
Baile, C.A. and McLaughlin, C.L. (1987): Mechanisms controlling feed intake. J.Anim. Sci., 64: 915-922.

Balnave, D. and Yoselewitz, I. (1988): Salinity of drinking water affects egg shell quality. Foodstuffs J., 60: 21.

Challies, D.J.; Zeinstra, J.S. and Anderson, M.J. (1987): Some effect of water quality on the performance of high yeilding cows in an arid climates. Vet. Rec., 120: 12.

Cheeke, P.R. (1987): Rabbit feeding and nutrition. Academic Press, London.

Crane, R.K. (1965): Sodium dependent transport in the intestine and other animal tissues. Fed. Proc., 24: 1000.

Dandliker, W.B. and Feigen, G.A. (1970): Quantification of the antigen-antibody reaction by polarization immunochemistry. Immunochemistry, 7: 799-828.

Dandliker, W.B. and Saussure, D.V. (1973): Review article: fluorescent polarization immunoassay. Theory and experimental method. Immunochemistry, 10: 219-227.

Elizabeth, A.Y. and Huda, A. (1985): Corticotropin releasing factor stimulation of adrenocorticotropin and B-endorphin release: Effect of acute and chronic stress. Endocrinology, 117: 23-30.

Ellefson, R.D. and Garaway, W.T. (1982): Lipids and lipoproteins. In: Fundamentals of clinical chemistry. Saunders Co., Philadelphia, pp. 474-541.

Gary, L.C. and Narang, N. (1985): Renal adaptation to potassium in the adrenalectomized rabbits. Role of distal tubular sodium potassium adenosines triphosphate. J. Clinical Investigation, 76: 1065-1070.

Grodsky, G.M. (1979): Chemistry and function of hormones. In: review of physiological chemistry. $17^{\text {th }}$ Ed., Lang Medical Publication, California, USA. 
Guyton, A. and Hall, J.E. (1996): Textbook of medical physiology. $9^{\text {th }}$ Ed., W.B. Saunders, Philadelphia, USA.

Jakubowski and Terkel, J.(1986): Establishment and maintenance of maternal responsivness in postpartum wistar rats. Anim. Behav., 34: 256 - 262.

Kamel, T.H.; Habeeb, A.A.; El-Masry, K.A.; Abdel-Samee, A.M. and Aboulnaga, A.I. (1984): Effect of breed and diluted sea drinking water on water turnover rate, total body water and total body solids in goats. $1^{\text {st }}$ Egyptian British conference on animal and poultry production, Univ. of Zagazig, Egypt.

Linder, H. R. (1959): Blood cortisol in sheep : Normal concentration and changes in ketosis of pregnancy. Nature, 184, Suppl. 21: 1645 .

Mervat, M. Kamel (1993): The effect of food deprivation on maternal behaviour and pup development in albino Norway rats. Vet. Med. J. Giza, 41 (1): 123 - 127.

Minton, J. E. and Blecha, F. (1990): Effect of acute stressors on endocrinological and immunological functions in lambs. $\mathrm{J}$. Anim. Sci. , 68: 3145 - 3151.

Muller, R.K. (1995): Toxicological analysis. Molina press, Leipzig, Germany.

Numan, M. (1978): Progesterone inhibition of maternal behaviour in the rat. Hormones and Behaviour, 11: 209 - 231.

Parrott, R. F. ; Lioyd, D. M. and Goode, J. A. (1996): Stress hormone responses of sheep to food and water deprivation at high and low ambient temperatures. Animal Welfare, 5: 45-56.

Paterson, J. Y. F. (1964): The distribution and turnover of cortisol in sheep. $J$. Endocrinol., 28: 183.
Pond, W.G.; Chuch, D.C. and Pond, K.R. (1995): Basic animal nutrition anf feeding. $4^{\text {th }}$ Ed., Wiely and Sons, New York, Chichester, Brisbane, Toronto and Singapore.

Ray, D.E. (1989): Interrelationships among water quality, climate and diet on feed lot performance of steer calves. J. Anim. Sci., 67: 357-361.

Sandford, J.C. (1996): Nutrition and feeding of the domestic rabbit. $5^{\text {th }}$ Ed., Blackwell Science.

SAS (1995): Statistical analysis system. User's Guide: Statistics. Version 6, $2^{\text {nd }}$ Ed., SAS Inst. Inc. , Cary, NC.

Shutt, D. A. ; Smith, A. I. ; Wallace, C. A. ; Connell, R. and Fell, L. R. (1988): Effect of Myiasis and acute restraint stress on plasma levels of immunoreactive BEndorphin, adrenocorticotrophin and cortisol in sheep. Aust. J. Biol. Sci. , 41: 297-301.

Suckow, M.A. and Douglas, F.A. (1997): The laboratory rabbit. CRC Press, Boca Raton, New York.

Tietz, N.W. (1982): Fundamentals of clinical chemistry. Saunders Company, Philadelphia.

Tomas, F.M.; Jones, G.B.; Potter, J. and Langsford, G.L. (1973): Influence of saline drinking water on mineral balance in sheep. Aust. J. Agric. Res., 24: 377-386.

Tyler, D.D. (1979): Water and mineral metabolism. In: Physiological chemistry. $17^{\text {th }}$ Ed., Lang Medical Publication, California, USA.

Willis, M.B. (1991): Dalton`s introduction to practical animal breeding. Blackwell Science, Oxford. 
تأثير شرب المياه الجوفية على معدل النمو والسلوك وبعض مكونات الام فى الأرانب

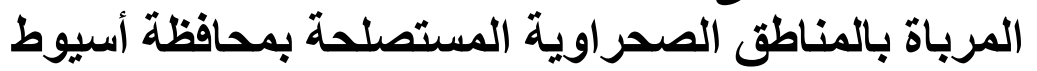

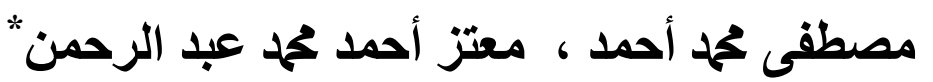

$$
\begin{aligned}
& \text { قسم صحة الحيوان - كلية الطب البيطرى - جامعة أسيوط. } \\
& \text { * سلوكيات ومعاملة الحيوان البطري جان }
\end{aligned}
$$

أجريت هذه التجربة بغرض دراسة تأثير استذام المياه الجوفية لسقى الأرانب المرباة بالمزارع المنثأة بالمناطق

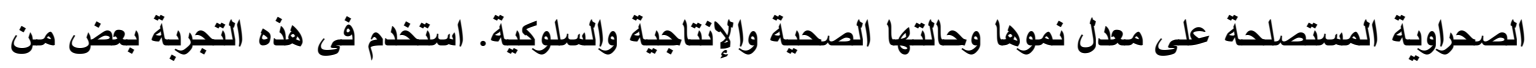

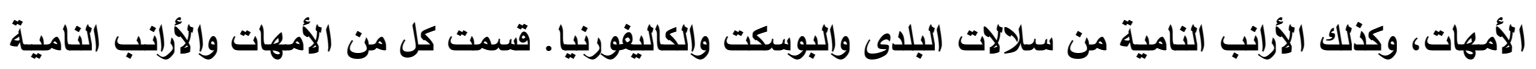

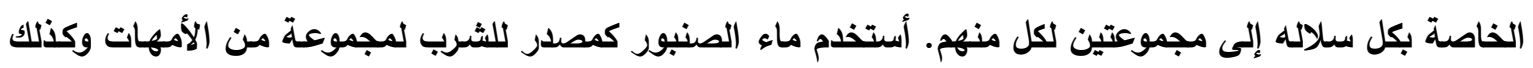

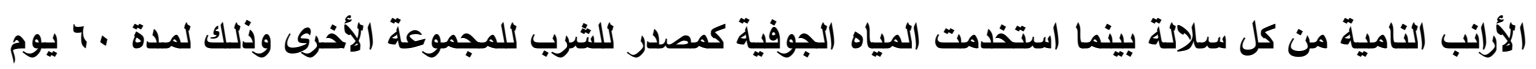

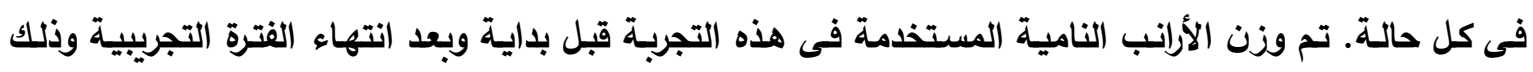

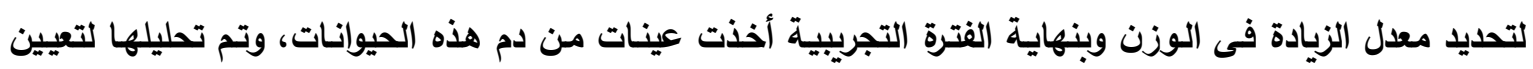

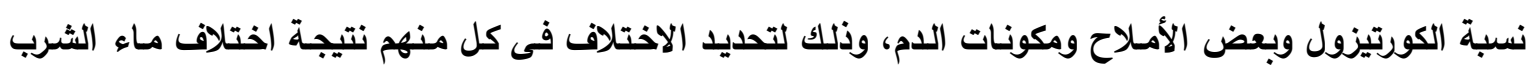

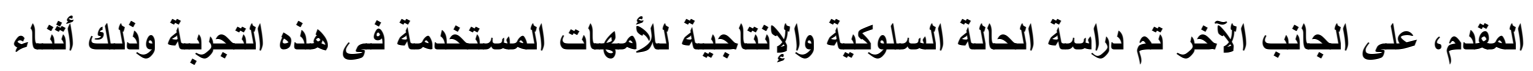

وبعد انتهاء الفترة التجريبية.

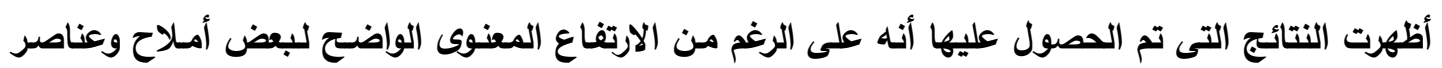

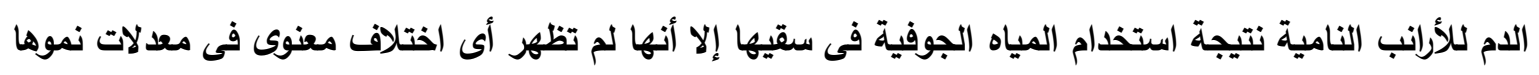

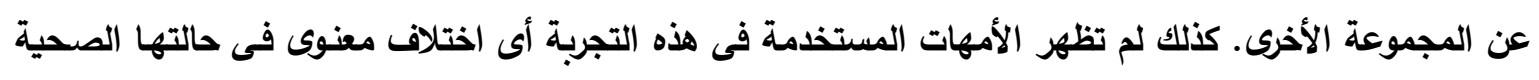

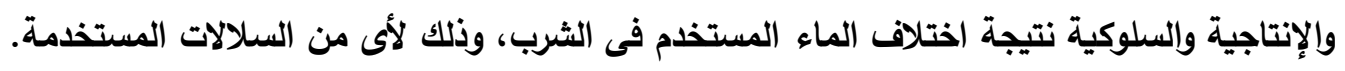

